\title{
Naloxone reverses the hypnotic effect and the depressed baroreceptor reflex of halothane anaesthesia in the dog
}

In order to evaluate the effect of an opioid antagonist on depressed intrinsic central vaso-motor drive (carotid sinus reflex) and high voltage slow delta waves in the $E E G$ associated with halothane, naloxone was injected intravenously in a bolus of 100 or $200 \mu \mathrm{g} \cdot \mathrm{kg}^{-1}$ on different days in the anaesthetized dog 10.64 Vol\% halothane in oxygenl. Only the $200 \mu \mathrm{g} \cdot \mathrm{kg}^{-I}$ dose of naloxone reversed the halothane-induced depression of the blood pressure and heart rate response to clamping of both exteriorized common carotid arteries. The EEG changed from high volsage slow waves to low voliage fast waves, inducing a reduction of power in the delta band in spectral analysis. This effect was most pronounced during the 20th minute post naloxone injection. Naloxone did not reverse the halothane-related hypotension and bradycardia. Because of the late "cortical arousal" reaction during halothane-anaesthesia and the high dose necessary, naloxone appears to exert its action througho generalized increase in CNS excitation. An antagonisation of halothane-induced release of opiate-like peptides therefore is less likely.

\section{Key words}

ANTAGONISTS, NARCOTIC: naloxOne; ANAESTHETICS, VOLATILE: halothane; BRAIN: electroencephalography, power spectral analysis.

From the Department of Anaesthesiology, University of Düsseldorf, and the Department of Central Diagnostics, Clinics for Psychiatry, Hufelandstrasse.

Address correspondence to: Dr. E. Freyc, Universitätskliniken, Moorenstrasse 5, 4000 Düsseldorf 1, Federal Republic of Germany.
The opiate-antagonist naloxone has been used successfully to reverse non-opiare induced respiratory, cardiovascular, and central nervous depression. This has included reversal of diazepaminduced respiratory depression' and diazepanrelated central nervous system depression in man. ${ }^{2}$ Reversal by naloxone of experimental endotoxic, electro-convulsive, and hypoyolemic shock in the rat has been demonstrated, ${ }^{3-5}$ while an increase in the $\mathrm{LD}_{50}$ of pentobarital in the rat was postulated to be another beneficial effect of the antagonist. ${ }^{6}$ Additionally, naloxone had been reported to be a useful drug in the treatment of severe catatonic schizophrenia and of ethanol intoxication. ${ }^{7}$ In patients comatose due to the combined effect of barbiturates, alcohol and diazepam, naloxone reversed the non-opiate induced apnea. ${ }^{8}$

Antagonization of endogenous opioids (enkephalins or endorphins) at opiate binding sites in the CNS is proposed as the mechanism of action of naloxone. Others, however, question the secondary release of endogenous opioids by non-opiate anaesthetics and sedatives. They were unable to demonstrate any beneficial effect of naloxone administration in diazepam-sedation, ${ }^{9}$ thiopental anaesthesia in $\operatorname{man}^{10}$ and in the pentobarbital anaesthesia in mice. ${ }^{11}$

Similarly, there have been confiicting reports on the effect of naloxone in reversing halothane and/or nitrous-oxide anaesthesia. The original positive results of Finck and Berkowitz in the rat, ${ }^{12}$ later corroborated by Yang et al. in man ${ }^{13}$ have not been confirmed by other laboratories. ${ }^{14-19}$

Since we had previously demonstrated that cerebro-ventricular perfusion of naloxone reversed the 
hypnotic effect and depressed baroreceptor reflex activity during halothane anaesthesia, ${ }^{18}$ the following study was undertaken in order to evaluate whether intravenous naloxone is able to induce similar antagonistic effects. Three questions were of particular interest.

1 Is naloxone able to reverse halothane-induced hypnosis and the depressed carotid sinus reflex?

2 At what time after the injection does naloxone reverse the halothane-depressed carotid sinus reflex?

3 What is the most effective dose of the antagonist?

\section{Materials and Methods}

Six dogs chronically prepared for repetitive arterial blood pressure measurement in the awake state were used for the experiments. Mean arterial blood pressure was measured via a Statham P 32 transducer through one of the previously exteriorized carotid loop arteries, ${ }^{20}$ and heart rate was derived from the ECG (lead II) by means of a cardiotachometer-coupler (Mingograph, SiemensElema). By clamping both exteriorized common carotid arteries, carotid-sinus mediated reflex effects on blood pressure and heart rate were evaluated. EEG activity of the frontal region was detected by electrodes which were plastered to the animal's scalp using colloidon in position $C_{3} / C_{4}$. The indifferent electrode was placed on the dog's nasal bone. ${ }^{21}$ The neuronal activity was amplified by a Schwarzer EEG recorder (time constant $0.3 \mathrm{~s}$ and cut off frequency at $30 \mathrm{~Hz}$ ) and recorded on chart as well as on magnetic tape (Philipps Analog 7). The recordings on the magnetic tape were later used for computerized power spectral analysis (Plurimat-S).

Representative examples of power spectra of the frontal cortical activity during wakefulness were used for the evaluation of the state of consciousness during the halothane anaesthesia, as well as during the time course of different doses of naloxone (100 and $200 \mu \mathrm{g} \cdot \mathrm{kg}^{-1}$ ).

\section{Analysis of the EEG}

Power spectral analysis of the EEG was performed with a digital computer based signal analyser (Plurimat-S) from artefact-free $200 \mathrm{~s}$ recordings after signal conditioning with an active bandpass filter (Krohn Hite Model 33 43, Butterworth type with a frequency band between 0.25 to $30 \mathrm{~Hz}$ ).

The spectra were used to determine the state of wakefulness. The computer was programmed to divide the EEG spectrum into various frequency bands:

$$
\begin{aligned}
12.50-20.00 \mathrm{~Hz} & =\text { beta-band (awake) } \\
8.00-12.50 \mathrm{~Hz} & =\text { alpha-band (drowsiness) } \\
4.10-8.00 \mathrm{~Hz} & =\text { theta-band (light sleep) } \\
0.25-4.10 \mathrm{~Hz} & =\text { delta-band (deep sleep) }
\end{aligned}
$$

The mean power spectra were averaged from 10 epochs (each with a duration of $20 \mathrm{sec}$ ), and the results displayed on a Tektronix ${ }^{R} 4010$ display terminal and copied by a Tektronix ${ }^{R} 4631$ hard copy unit. Logarithmic scaling was chosen for a reasonable representation of both the power ( $y$ axis) and frequency ( $x$-axis).

Power spectrum or energy spectrum determines

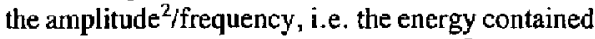
in a wave per entity or bandwidth $\left(\mathrm{MV}^{2}\right)$.

\section{Experimental protocol}

After control measurements during the awake state, anaesthesia was induced with methohexital $(5 \mathrm{mg}$. $\mathrm{kg}^{-1}$ i.v.). The animals were then intubated and attached to an anaesthesia machine (Dräger Romulus), breathing spontaneously while anaesthesia was maintained with halothane using a calibrated vapourizer (Dräger Vapor) at a concentration starting with $1.5 \mathrm{Vol} \% / \mathrm{O}_{2}$. This concentration was gradually reduced until a constant end-tidal halothane concentration was reached which just left the animals unconscious and unresponsive to painful stimuli such as nose clamping. Generally, a concentration of about $0.65 \mathrm{Vol} \%$ halothane in oxygen was required, as measured by a gas analyser (Engström Multigas Monitor). Mean arterial blood pressure, heart rate and EEG frontal activity were continuously recorded on a Mingograph recorder (Siemens-Elema).

After 60 minutes, end-expiratory halothane concentration remained stable, suggesting equilibration of alveolar and brain anaesthetic concentrations. During this time, both common carotid arteries were clamped on three occasions. Naloxone was then given intravenously in a bolus injection of $100 \mu \mathrm{g} \cdot \mathrm{kg}^{-1}$.

Both common carotid arteries were clamped for one minute in order to evaluate carotid sinus reflex activity, as reflected in the amount of the increase in blood pressure and heart rate at 5, 10, 15, 20, 25 and $30 \mathrm{~min}$ after naloxone injection.

On the following day, the same animal was 


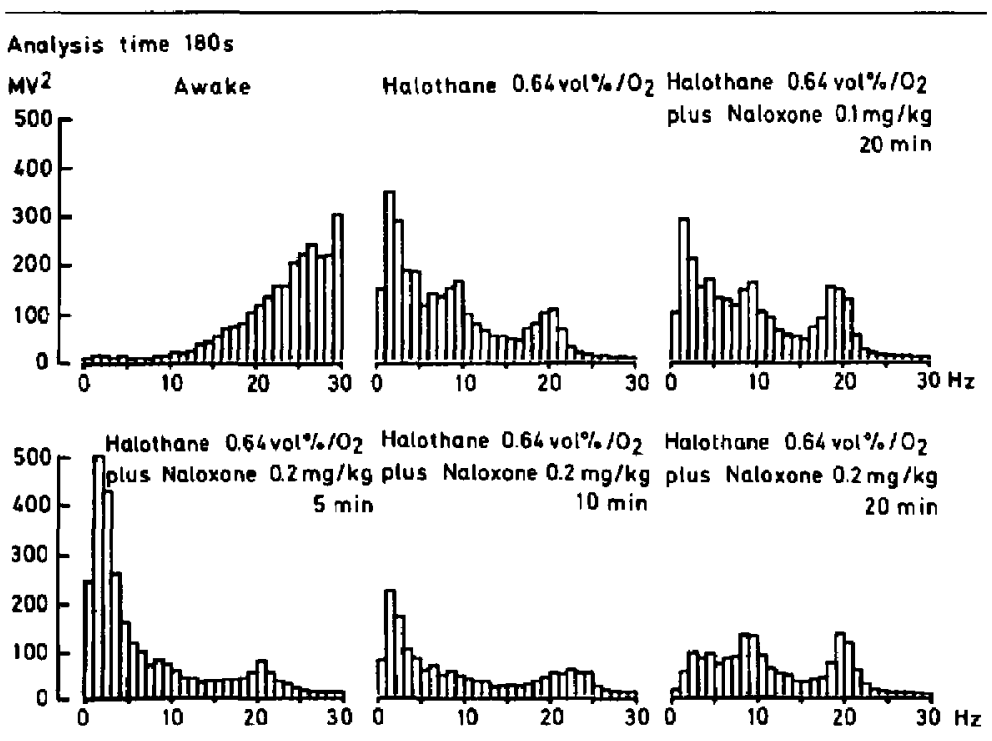

FIGURE I Representative example of the EEG power spectral analysis of the awake state, during halothane anaesthesia, during halothane anaesthesia plus naloxone $0.1 \mathrm{mg} \cdot \mathrm{kg}$, and during halothane anacsthesia plus naloxone $0.2 \mathrm{mg} \mathrm{kg}^{-1}$. NOTE: a diminution of power maxima in the lower frequency band $(0.5-5 \mathrm{~Hz})$ reflecting an arousal reaction which is most prominent around the 20 th minute after naloxone $0.2 \mathrm{mg} \cdot \mathrm{kg}^{-1}$ injection.

exposed to the same halothane concentrations and procedures, this time receiving naloxone in a dose of $200 \mu \mathrm{g} \cdot \mathrm{kg}^{-1}$.

\section{Statistical Evaluation}

Data obtained during pure halothane anaesthesia were compared to data for the $5,10,15$, and 20 minute points following naloxone injection, using the two-tailed test of Wilcoxon-Rank. Statistical significance was considered as $p \leqslant 0.05$.

\section{Results}

The EEG power spectral analysis, reflecting the state of consciousness, shows that contrary to the awake control state with a dominant power in the beta-band $(15-30 \mathrm{~Hz})$, halothane anaesthesia induced a shift of power maxima to the lower frequency band, ranging from theta to delta $(0.5-$ $8 \mathrm{~Hz}$ ), the latter resembling a state of unconsciousness and hypnosis.

This change is demonstrated in a representative example (Fig. 1) where the additional administration of naloxone $100 \mu \mathrm{g} \cdot \mathrm{kg}^{-1}$ during halothane (0.64 Vol\% in pure oxygen) induces only a small increase in power in the higher frequency band around $20 \mathrm{~Hz}$. A dose of $200 \mu \mathrm{g} \cdot \mathrm{kg}^{-1}$, however, gradually induces a reduction of power maxima of the delta-band $(0.25-4 \mathrm{~Hz})$, which finally results in a shift of power from the low to the higher frequency band $(15-30 \mathrm{~Hz})$ in the 20 th min post injection.

The percentage change in power of the various frequency bands of six experiments during halothane anaesthesia and after $\left(20^{\prime}\right)$ naloxone injection is summarized in Table 1 . It can be seen that in the delta $(0.5-3.5 \mathrm{~Hz})$ and alpha-band $(7.5-13 \mathrm{~Hz})$ there is a significant decrease of power $(\mathrm{p}<0.05)$ while in the higher frequency bands $(18-25 ; 25-$ $30 \mathrm{~Hz})$ only beta $4(25-30 \mathrm{~Hz})$ demonstrates a significant increase $(p=0.05)$. These changes in cortical activity can be labelled as arousal.

These time dependent changes in EEG activity are demonstrated in another representative example (Fig. 2) showing the amplified neuronal activity of the frontal cortex as they are originally recorded. From the awake state with high frequency, low amplitude waves, cortical activity changes into low frequency, high amplitude waves when halothane has been administered for $60 \mathrm{~min}$. Naloxone injec- 
TABLE I Summary of EEG results

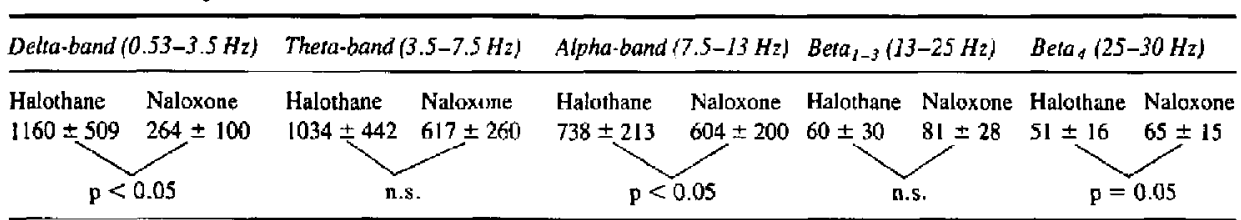

Per cent change in the total activity of the EEG-frequency bands compared to awake-control. Results of six experiments \pm SEM. Halothane induces a marked increase of power in the delta- and theta-bands; subsequent naloxane injection $\left(200 \mu \mathrm{g} \cdot \mathrm{kg}^{-1}\right)$ induces a reduction in delta, theta and alpha and an increase of total power in the beta-band.

The $\mathrm{t}$-test for paired observations (halothane-naloxonc) is significant in delta, alpha, and beta, indicating "arousal."

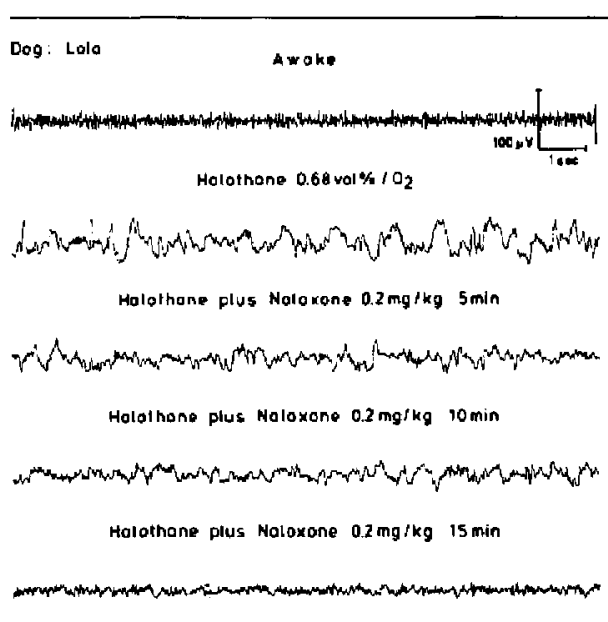

Holothane pius Naloxane 02 mg $/ \mathrm{kg}$. $25 \mathrm{~min}$

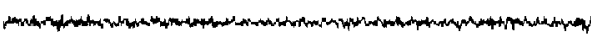

Haloinane plus Noloxane $0.2 \mathrm{mg} / \mathrm{kg} 30 \mathrm{~min}$

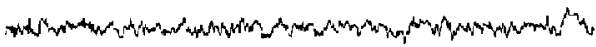

Holothone plys Nalarane $0.2 \mathrm{mg} / \mathrm{kg} 35 \mathrm{~min}$

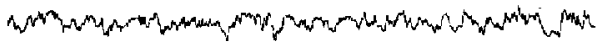

FIGURE 2 Representative example of EEG activity during the awake state, during halothane anaesthesia, and during different time intervals after naloxone $0.2 \mathrm{mg} \mathrm{kg}^{-1}$ injection. NoTE: low frequency, high amplitude waves, characteristic for the anaesthetic state are gradually reversed by naloxone to high frequency, low amplitude waves, the latter representing a picture similar to the awake state. This effect is pronounced around the 20th to 25th min post injection. Thereafter the arousal effect wears off and at the 3 sth minute a pattern similar to the halothane anaesthetic state is again dominant. tion in a bolus of $200 \mu \mathrm{g} \cdot \mathrm{kg}^{-1}$ gradually reverses this pattern, inducing EEG activity which is similar to the awake control state, at about 20 to 25 minutes following injection. Thereafter the naloxone effect wears off, and a pattern with low frequency, high amplitude waves, similar to pure halothane anaesthesia, becomes dominant.

The time dependent changes in EEG activity coincide with a change in the animals' behaviour: From a state of unresponsiveness to noxious stimuli, i.e. nose clampling, naloxone injection induced hyperventilation, moving and stiffening of the head until finally the animals opened their eyes while some of them reacted to the tracheal tube.

Compared to the control conscious state, halothane induced characteristic cardiovascular changes: bradycardia, hypotension, and depression of the baroreceptor reflex. These changes were gradually reversed by naloxone $200 \mu \mathrm{g} \cdot \mathrm{kg}^{-1}$ i.v., as demonstrated in Fig. 3. At about 15 to 20 minutes after injection of the naloxone there was a significant increase in baroreceptor activity when compared to halothane anaesthesia alone. This effect is so pronounced that control values of the conscious state are reached. Thereafter the increased reflex activity shows a gradual decline to the halothane anaesthesia levels.

While naloxone was able to reverse the halothaneinduced depression of the carotid sinus reflex, there was no such effect on the anaesthesia-induced hypotension and bradycardia.

\section{Discussion}

These results demonstrate that naloxone is able to reverse halothane-induced depressed baroreflex activity and hypnosis, but not the anaesthesiarelated hypotension and bradycardia. The exact site of action of naloxone cannot be distinguished from 


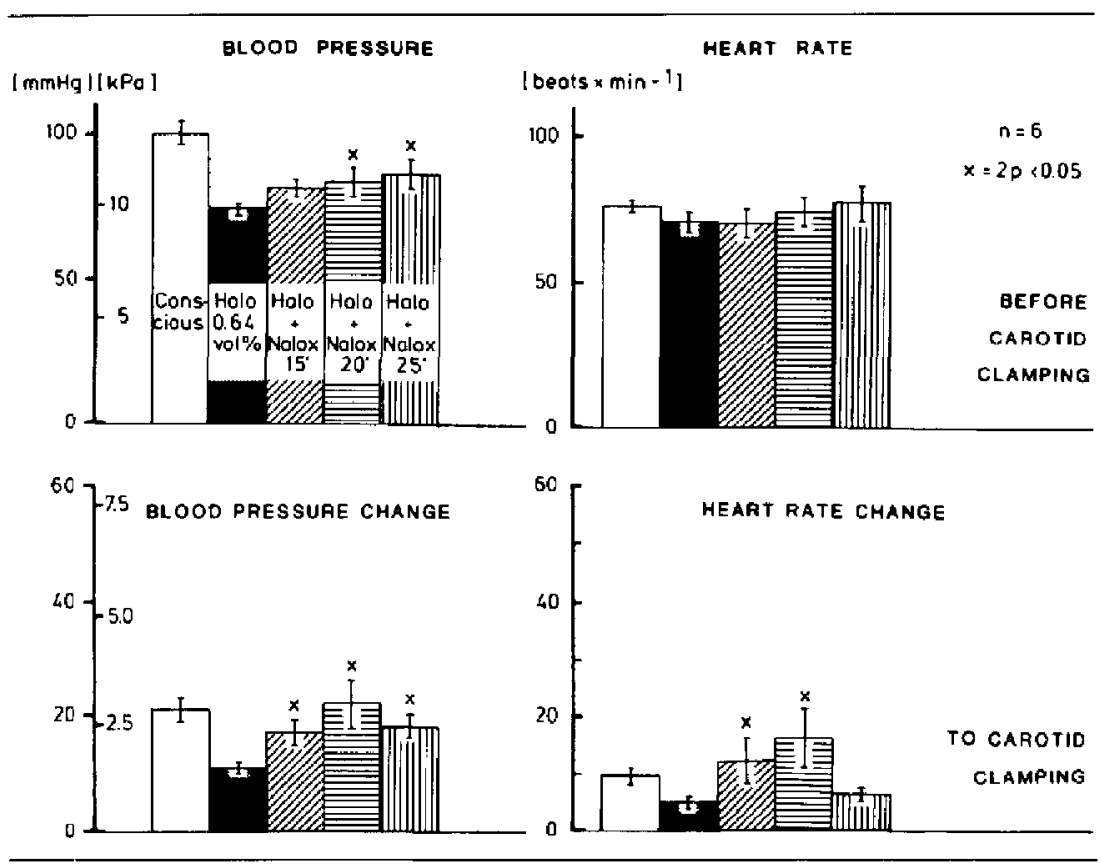

FIGURE 3 Mean blood pressure, heart rate, and their response to bilateral clamping of both common carotid arteries in the awake state, during halothane anaesthesia, and during various time intervals after naloxone injection Mean \pm SEM of 6 experiments. Note: the halothane depressed occlusion reflex of the carotid sinus is reactivated by nalcixone reaching awake control levels. This effect is most pronounced around the 20th minute post injection.

the present study. The antagonist might for example exert a direct effect on the sensitivity of the carotid sinus stretch receptors. It might, howcver, also have a direct effect on the vasomotor centers within the brain-stem which supply the efferent output. Previous experiments using the selective perfusion technique in the halothane anaesthetized dog, indicate that the naloxone arousal reaction is initiated from a structure bordering the fourth cerebral ventricle. ${ }^{18}$ Since stereospecificity was demonstrater, opiate binding sites were postulated as a class of putative receptors interacting with halothane-released endogenous opiate-like peptides.

These earlier findings and the EEG changes seen following naloxone indicate a central effect of the antagonist. The present results show that in contrast to the well-established competitive antagonism of opiate effects by naloxone within two to five minutes, initiation of an arousal reaction during halothane anaesthesia only developed fully 20 minutes following injection. This long latency suggests that a direct interaction with the opiate receptors is unlikely.

If naloxone displaces endogenous opioids competitively from opiate receptors, a great deal less naloxone than $200 \mu \mathrm{g} \cdot \mathrm{kg}^{-1}$ should have been required for total opiate receptor occupation in the CNS. For instance, only $5 \mu \mathrm{g} \cdot \mathrm{kg}^{-1}$ of naloxone is necessary to reverse the respiratory, circulatory and EEG effects of $210 \mu \mathrm{g} \cdot \mathrm{kg}^{-1}$ of morphine within two to four minutes ${ }^{22}$ when the brain concentration of naloxone is expected to be high. ${ }^{23}$ These differences in the dose requirements and time courses of the antagonistic effect in opiate anaesthesia and the initiation of an "arousal" reaction during halothane anaesthesia imply that the receptors involved in the centrally mediated analeptic reaction may have unique properties, distinct from specific opiate binding sites.

Such a non-antagonistic but analeptic effect of naloxone on the state of consciousness in patients after anaesthesia has been considered by Aldrete 
and Goldman. ${ }^{24}$ Similarly Chapman and Benedetti $^{25}$ demonstrated a non-specific and partial reversal of the central depressive effect of nitrous oxide on cerebral evoked potentials in man and Artu et al. $^{26}$ noted a naloxone-induced rise in EEG frequency with a concomitant fall in amplitude, in the halothane anaesthetized dog, as in the present study. Non-specific EEG arousal reactions of the antagonist are reported by Roy and Stullken ${ }^{27}$ where naloxone as well as doxapram and physiostigmine were able to reverse EEG effects of sub-MAC halothane.

Last but not least, the selectivity of naloxone for opiate binding sites has been questioned because of evidence that the compound also blocks gammaaminobutyric acid (GABA), a transmitter which inherits inhibitory properties in the CNS. ${ }^{28}$

Why, however, did other researchers fail to detect any effect of naloxone on halothane anaesthesia? In these studies ${ }^{14,15,19}$ naloxone in high to massive doses $\left(2000-2500 \mu \mathrm{g} \cdot \mathrm{kg}^{-1}\right)$ did not reverse nitrous-oxide- or halothane-induced depression of the writhing response in the rat. First is the notion that a massive dose of the essentially "pure" antagonist naloxone may unmask morphinomimetic properties such as miosis and sedation reactions which have been observed in the $\operatorname{dog} .{ }^{29}$ Second is the concept that naloxone binds preferentially to the $\mu$-type opiate receptor, ${ }^{30}$ a subunit of opiate binding sites as originally described by Martin et al. ${ }^{31}$ Opioid peptides correspond more to the deltareceptor, ${ }^{32}$ another subpopulation of opiate receptors with which selective $\mu$-agonists (e.g. morphine or fentanyl) or a $\mu$-selective antagonist (e.g. naloxone) show less affinity, ${ }^{33}$ If halothane really does induce the release of endogenous opioid peptides (enkephalins or endorphines), then naloxone can be considered as a poor delta-receptor antagonist. ${ }^{32,33}$ Other more specific antagonists might be more useful in reversing halothane-induced changes.

Thirdly, there is suspicion that different strains of animals may possess different subpopulations of opiate-receptors, binding sites which demonstrate reduced interaction with the opiate antagonist naloxone. Such a view is reinforced by experiments where naloxone was unable to change the nociceptive threshold in normotensive rats, but induced a decreased nociceptive threshold in spontaneously hypertensive rats. ${ }^{34}$

This study has demonstrated a possible favour- able role of the antagonist naloxone on emergence from halothane anaesthesia. Such a beneficial effect may only be obvious when low concentrations of halothane are present, as in the immediate postanaesthetic period. Naloxone may then lead to a more rapid normalisation of halothane depressed blood pressure and heart rate regulating reflexes and of reduced consciousness. However, it remains to be determined what dose regimen is necessary to elicit similar effects in man.

\section{Acknowledgements}

The stylistic aid of Miss Jana Bosco and the secretarial work of Miss Heidrun Hamatschek is gratefully acknowledged.

\section{References}

1 Tech CJB, Lehane JW, Jones JG. Respiratory depression following diazepam: Reversal with highdose naloxone. Anesthesiology 1980; 53: 293-8.

2 Bell EF. The use of naloxone in the treatment of diazepam poisoning J Pediatr 1975; 87: 803-4.

3 Holaday $J W$, Faden AI. Naloxone reversal of endotoxin hypotension suggests role of endorphine in shock. Nature 1978, 275; 450-1.

4 Faden AV, Holaday JW. Opiate antagonists: A role in the treatment of hypovolemic shock. Science 1979; 205: 317-8.

5 Belensky GL, Holaday JW. The opiate antagonist naloxone modifies the effects of electroconvulsive shock (ECS) on respiration, blood pressure and heart rate. Brain Res 1979; 177: 414-7.

6 Fürst $Z$. Foldes $F F$, Knoll $J$. The infuence of naloxone on barbiturate anesthesia and toxicity in the rat. Life Sci 1977; 20: 921-6.

7 Schenk GK, Enders $P$, Engelmeier MP, et al. Application of the morphine antagonist naloxone in psychic disarders. Drug Res 1978; 8: 1274-7.

8 Moss LM, Naloxone-teversal of non-narcotic induced apnea. J Am Coll Phys 1973; 1: 46-8.

9 Christensen $K N$, Hüttel $M$. Naloxone does not antagonize diazepam-induced sedation. Anesthesiology 1979; $51: 187$.

10 Duncalf $D$, Nagashima $H$, Duncalf $R M$. Naloxone fails to antagonize thiopental anesthesia. Anesth Analg 1978; 57: 558-62.

11 Bhargava $H N$. Studies of the possible role of brain endorphine in pentobarbital anesthesia and toxicity in mice. Anesthesiology 1979; 51:398-401.

12 Fink $A D$, Berkowitz BA. Antagonism of general 
anesthesia by naloxone in the rat. Anesthesiology 1977; 46: 241-5.

13 Yang JC, Clark WC, Ngai SH. Antagonism of nitrous oxide analgesia by naloxone in man. Anesthesiology 1980; 52: 414-7.

14 Smith RA, Wilson $M$, Miller $K W$. Naloxone has no effect on nitrous oxide analgesia. Anesthesiology 1978; 49:6-8.

15 Harper MH, Winter PM, Johnson BH, et al. Naloxone does not antagonize general anesthesia in the rat. Anesthesiology 1978; 49: 3-5.

16 Bennett $P B$. Naloxone fails to antagonize the righting response in rats anesthetized with halothane. Aulesthesiology 1978; 49: 9-11.

17 Pace NL, Wong KC. Failure of naloxone and naltrexone to antagonize halothane anesthesia in the dog. Anesth Analg 1979; 58: 36-9.

18 Arndt JO, Freye $E$. Perfusion of naloxone through the fourth cerebral ventricle reverses the circulatory and hypnotic effects of halothane in dogs. Anesthesiology 1979; 51: 58-63.

19 MacLead BA, Ping PC, Jenkins LC. The absence of antagonism by naloxone during halothane'nitrous oxide anesthesia in man. Can Anaesth Soc J 1980; 27: 29-32.

20 van Leersum EG. Eine Methode zur Erleichterung der Blutdruckmessung an Hunden. Pflügers Arch ges Physiol 1911; 142: 377.

21 Werner J, Janitschke $K$, Hildebrand-Nowski E. Eine fortlaufende Schlafticfenmessung mittels Elektroenzephalo-Elektrookulographie (EEG und EOG) beim Hund. Zentralb] Veterinärmed 1962; 9 : 565-91.

22 Hasbrouck ID. The antagonism of morphine anesthesia by naloxone. Anesth Analg 1971; 50: 954-8.

23 Ngai SH, Berkowitz BA, Yang JC, Hempstead J, Spector $S$. Pharmacokinetics of naloxone in rats and in man. Anesthesiology 1976; 44: 398-401.

24 Aldrete JA, Goldman $E$. Is naloxone a nonspecific araleptic? Anesthesiology 1979; 50: 270-1.

25 Chapmen $C R$, Benedetti $C$. Nitrous oxide effects on cerebral eyoked potential to pain. Anesthesiology 1979; 51: 135-8.

26 Artu AA, Steen PA, Michenfelder JD. Cerebral metabolic effects of naloxone. Anesthesiology 1979; $51: 46$.

27 Roy RC. Stullken EH. EEG arousal by doxapram, naloxone, and physostigmine. Anesthesiology 1979; 51: 47.

28 Dingledine $R$, Iversen $L L$, Breuker $E$. Naloxone as a GABA antagonist: Evidence from iontophoretic, receptor binding and convulsant studies. Eur J Pharmacol 1978; 47: 19-27.

29 Jacob JJ, Michaud MG. Production par la naloxone d'effets inverses de ceux de la morphine chez le chien éveillé. Arch int Pharm 1976; 222: 332-40.

30 Wüster $M$, Schulz $R$, Herz A. Specificity of opioids towards the $\mu$-, $\delta$-, and $\epsilon$-opiate receptors. Neuroscience Letters $1978 ; 15 ; 193-8$.

31 Martin WR, Eades CG, Thopson JA, Huppler RE. Gilbert $P E$. The effect of morphine and morphinelike drugs in non-dependent and morphine-dependent chronic spinal dogs. J Pharmacol Exp Ther 1976; 197: 517-32.

32 Lord JAH, Waterfieid AA, Hughes J, Kosterlitz HW. Endogenous opioid peptides: Multiple agonists and receptors. Nature (London) 1977; 267: 495-9.

33 Wüster M, Schulz R, Herz A. 1977; Opioid antagonists and agonists: Action on multiple opiate receptors. In: Way EL (ed.), Exogenous and Endogenous opiate agonists and antagonists. Pergamon Ptess, New York 1980.

34 Delbarre B. Casset-Senon D, Delbarre G, Sestillange $P$, Christian $P$. Naloxone effects on blood pressure, analgesia and diuresis in spontaneous hypertensive and normotensive rats. Neurosci Lett 1982; 30: 167-72.

\section{Résumé}

Pour rechercher les effets d' un opiacé antagoniste sur la réduction du baroréflexe déprimé du sinus carotidien et sur la vigilance diminuée par une narcose da l'halathane $\left(0.64\right.$ Vol\% dans $\left.\mathrm{O}_{2}\right)$, la naloxone a été administrée deux jours de suite da la dose respective de 100 et $200 \mu \mathrm{g} \cdot \mathrm{kg}^{-1}$ en injection intraveineuse. Seulement la dose de $200 \mu \mathrm{g}$. $\mathrm{kg}^{-1}$ de naloxone a permis d' antagoniser l' effet central induit par l'halothane, la régulation déficiente de la circulation du sirus carotidien et le ralentissement de l'onde de l'EEG. Cet effet est oblenu 20 minules apres l'injection. L'hypotension et la bradycardie caractéristiques de l'halothane peuvent ne pas être infiuencées par une injection intraveineuse de naloxone. Sur la base de la réaction de réveil induite tardivement par la naloxone ainsi que la haute dose nécessaire, l'effet ne semble pas être une antagonisation reposant sur l'endorphine libérée par l'halothane. Les bases des excitations du SNC semblent résulter d'une interaction avec d'autres neurones (peut-être zone GABA). Les recherches cliniques et pratiques de l'urilisation de hautes doses de naloxone après narcose gazeuse doivent être poursuivies. 